\title{
A Human Rights-based Approach to Combating Public Procurement Corruption in Africa
}

\author{
John C. Mubangizi \\ College of Law and Management Studies, University of KwaZulu-Natal, \\ Durban, South Africa \\ jcmubangizi@gmail.com

\section{Prenisha Sewpersadh} \\ Doctoral Graduate, School of Law, University of KwaZulu-Natal, Durban, \\ South Africa \\ psewpersadh@gmail.com
}

\begin{abstract}
Corruption is a threat to human rights as it erodes accountability and violates many international human rights conventions. It also undermines basic principles and values like equality, non-discrimination, human dignity, and social justice - especially in African countries where democratic systems and institutional arrangements are less developed than in most European, Asian and American countries. Corruption occurs in both the public and private sectors and affects human rights by deteriorating institutions and diminishing public trust in government. Corruption impairs the ability of governments to fulfil their obligations and ensure accountability in the implementation and protection of human rights - particularly socio-economic rights pertinent to the delivery of economic and social services. This is because corruption diverts funds into private pockets - impeding delivery of services, and thereby perpetuating inequality, injustice and unfairness. This considered, the focus of this paper is on public procurement corruption. It is argued that by applying a human rightsbased approach to combating public procurement corruption, the violation of human rights - particularly socio-economic rights - can be significantly reduced. Through a human rights-based approach, ordinary people can be empowered to demand transparency, accountability and responsibility from elected representatives and public officials - particularly those involved in public procurement. In the paper, reference is made to selected aspects of the national legal frameworks of five African countries: South Africa, Uganda, Kenya, Nigeria and Botswana.
\end{abstract}




\section{Keywords}

corruption - public procurement - Africa - human rights

\section{Introduction}

Corruption is generally seen as the abuse of public power for private gain. ${ }^{1}$ It affects and occurs within almost every facet of human life. Taking into account the definition of human rights as being those rights that one possesses by virtue of being human, corruption is indeed a threat to human rights. This is because it erodes accountability and violates many international human rights conventions. It also undermines basic principles and values like equality, non-discrimination, human dignity, and social justice. This is particularly so in African countries where democratic systems and institutional arrangements are less developed than in most European, Asian and American countries - for example.

Corruption occurs in both the public and private sectors, where it affects human rights by deteriorating institutions and diminishing public trust in government. It impairs the ability of governments to fulfil their obligations and ensure accountability in the implementation and protection of human rights - particularly socio-economic rights pertinent to the delivery of economic and social services like healthcare, education, clean water, housing, and social security. This is because corruption diverts funds into private pockets which impedes delivery of services, thereby perpetuating inequality, injustice and unfairness. Consequently, the focus of this paper is on public procurement corruption, and it is argued that by applying a human rights-based approach to combating public procurement corruption, the violation of human rights particularly socio-economic rights - can be significantly reduced. Through a human rights-based approach, ordinary people can be empowered to demand transparency, accountability and responsibility from elected representatives and public officials - particularly those involved in public procurement.

There are varying opinions on whether certain acts qualify to be denounced as corrupt. This can be seen from the various attempts to define corruption. Indeed, according to Anderson 'corruption is a term carrying many different

1 Vito Tanzi, 'Corruption around the world: Causes, consequences, scope and cures' (1998) 45 International Monetary Fund Staff Papers 564. 
and complex interpretations. ${ }^{2}$ He explains that the term is 'derived from the Latin corruptio, meaning depraved condition, state of decay or bribery [and has] traditionally been associated with moral decadence. ${ }^{3}$ Nye defines corruption as 'behaviour which deviates from the formal duties of a public role because of private-regarding (personal, close family, private clique) pecuniary or status gains; or violates rules against the exercise of certain types of private-regarding influence.4 Manzetti and Wilson define corruption as an illegal transaction where 'public officials and private sector actors exchange goods for their own enrichment at the expense of society at large. ${ }^{5}$

The various definitions of corruption tend to lead to a divergence of perspectives, that may even verge on inadvertent justification. According to RoseAckerman, for example

Corruption has different meanings in different societies. One person's bribe is another person's gift. A political leader or public official who aids friends, family members and supporters may seem praiseworthy in some societies and corrupt in others. ${ }^{6}$

This is particularly so in African societies where, it has been claimed, corruption is 'socially embedded ... due to different African practices, ways of living and beliefs. ${ }^{7}$ Referring to Nye's definition of corruption cited above, de Sarden argues that the illegality of the practices implied in that definition can be perfectly legal in other historical and social contexts. ${ }^{8}$ De Sarden claims that:

... everyone in Africa has routine experience in dealing with corruption (and the like), this being a part of the social landscape. It has even become

2 Staffan Anderson, 'Corruption in Sweden: Exploring danger zones and change' (2002) Research Report, Department of Political Science, Umea University, <http://www.diva -portal.org>.

3 Ibid.

4 J.S. Nye, 'Corruption and political development: A cost-benefit analysis' (1967) 61 American Political Science Review 419.

5 Luigi Manzetti \& Carole J. Wilson, 'Why do corrupt governments maintain public support' (2007) 40 Comparative Political Studies 950.

6 Susan Rose-Ackerman Corruption and government: Causes, consequences and reform (Cambridge University Press, 1995) 5.

7 J.P. Olivier de Sarden 'A moral economy of corruption in Africa' (1999) 37 Journal of Modern African Studies $25^{-52}$.

8 Ibid. 
a part of popular know-how, at the base of good usage of administrative services, and is indispensable for survival in the post-colonial milieu. ${ }^{9}$

This claim is indicative of certain questionable realities. Firstly, that corruption is almost a way of life in Africa and a part of the social landscape. Secondly, that it has found some form of acceptance - not in a legal sense, but from a social standpoint. Commenting on corruption in Nigeria, Smith stated that what may appear to be corruption to the onlooker is actually survivalist behaviour as people navigate Nigeria's 'clientelistic' political economy. ${ }^{10}$ It is for this reason that a human rights-based approach to combating public procurement corruption in Africa is called for.

Conceptually, public procurement has been defined as the process by which governments and regional and local public authorities or bodies governed by public law purchase products, services and public works.'11 Williams and Quinot define public procurement as the 'purchasing by a government of the goods and services it requires to function and pursue public welfare.'. ${ }^{12}$ Both definitions concur with the World Bank, which defines public procurement as 'the purchasing, hiring or obtaining by any other contractual means of goods, construction works and services by the public sector. ${ }^{\prime 3}$ It is alternatively defined as the purchase of commodities and contracting of construction works and services if such acquisition is effected by resources from state budgets, local authority budgets, state foundation funds, domestic loans or foreign loans guaranteed by the state, and foreign aid as well as revenue received from the economic activity of the state. ${ }^{14}$

While these definitions are all correct, it has been argued that they are narrow and inadequate in that they refer only to the acquisition element of procurement, while ignoring the equally important disposal element. ${ }^{15}$ This

$9 \quad$ Supra note 7 , p. 28.

10 D.J. Smith 'Kinship and corruption in contemporary Nigeria' (2001) 66 Ethnos 344-364.

11 Walter Kahlenborn, Christine Moser, Joep Frijdal \& Michael Essig (2011) Strategic use of public procurement in Europe. Final Report to the European Commission MAR KT/2010/02/C, p. 7 .

12 Sope Williams \& Geo Quinot 'Public procurement and corruption: The South African response' (2007) 124 South African Law Journal 340.

13 Andrea Appolloni \& Jean Marie Mushagalusa Nshombo, 'Public procurement and corruption in Africa: A literature review' (2013) 2 Rivista di Politica Economica $3<$ http://www. proxenter.it/public/proxenter/files/Apolloni-Mushagalusa_imp._Layout_1_.2.pdf>.

14 Ibid.

15 Phoebe Bolton The law of government procurement in South Africa (LexisNexis, Durban, 2007) 784 . 
argument has merit in that corruption may take place within both the acquisition and disposal aspects of procurement. That is why Wensik and De Vet have described public procurement as 'a multi-step process [that] involves the full cycle from needs assessment through the preparation of the procurement documentation and awarding of the contracts, the implementation and monitoring of the project'. ${ }^{16}$

In presenting arguments and arriving at the conclusion, reference is made to selected aspects of the national legal frameworks of South Africa, Uganda, Kenya, Nigeria and Botswana - based on the research interests of the authors of this paper. This survey is not exhaustive and is meant to present an overview of the types of legal frameworks potentially available for fighting public procurement corruption.

\section{$2 \quad$ Corruption and Human Rights}

It is against the above introductory and conceptual background that a human rights-based approach to combating public procurement corruption must be seen. But first, the link between human rights and corruption must be highlighted and explored. It is important to state that much has been said and written about the connection between corruption and human rights. What is discernible in the literature is that the link between corruption and human rights has two intertwined strands. The first is that corruption has an adverse impact on human rights - in other words, it negatively affects the enjoyment of human rights. The second is that corruption is a violation of human rights - in other words, acts of corruption directly or indirectly violate or infringe upon specific human rights norms. The following discussion is based on those two strands - beginning with the latter.

\subsection{Corruption as a Violation of Human Rights}

There is growing international recognition of the universality, interdependence and indivisibility of human rights. The principle of the universality of human rights is founded on the notion that all human rights apply uniformly and with equal force throughout the world. The principle of interdependence of all human rights holds that the full and meaningful enjoyment of a particular right is dependent on the possession of all the other rights, and the indivisibility of

16 Wim Wensink \& Jan Maarten de Vet Identifying and reducing corruption public procurement in the $E U$ (2013), <https://ec.europa.eu/anti-fraud/sites/antifraud/files/docs/body/ identifying_reducing_corruption_in_public_procurement_en.pdf $>$. 
human rights is founded on the assumption that all human rights have the same basic characteristics - and should be upheld through the medium of equally potent enforcement mechanisms. The inference from these principles is that human rights are universal and should apply to all persons at all times - without distinction. This is consistent with the fundamental human rights principles of equality and non-discrimination. Unfortunately, corruption produces unequal and discriminatory outcomes and perpetuates inequality. If corruption restricts a person's access to housing, healthcare, education, water and sanitation, the courts, or impinges on his/her right to a fair trial, it is discriminatory.

Inequality and discrimination may also be perpetuated through the state's inability to distribute resources in an equitable way because of corruption. When public funds are directly misappropriated from the government budget and diverted into the pockets of a few - inequality is perpetuated. When funds meant for infrastructure development and maintenance are abused, inequality is perpetuated. When public resources are mismanaged through corruption, the ability of government to deliver public services is compromised, the realisation of socio-economic rights - particularly for the poor - is affected, and inequality is perpetuated. As the Nigerian president stated recently:

For the masses of our people, the millions still wallowing in want and diseases, corruption is a major reason why they cannot go to school; why they cannot be gainfully employed; and why there are few doctors, nurses and drugs in their hospitals and health centres. It is the reason why pensioners are not paid and potable water is scarce. ${ }^{17}$

The protection of civil and political rights and the enjoyment of socio-economic rights, generally have a direct correlation with the level of economic development. It has therefore been argued that because corruption thwarts economic development, it leads to widespread poverty and directly violates people's socio-economic rights. ${ }^{18}$ It has been further argued that corruption can directly violate an individual's human rights, if, for example 'a corrupt government official takes a bribe to decide a case against an individual or a corrupt police officer takes a bribe not to investigate a case.19

\footnotetext{
17 President Buhari at opening of 55th Annual General Conference of Nigerian Bar Association, Abuja, 23 August 2015 .

18 Joel M. Ngugi 'Making the link between corruption and human rights: Promises and perils' (2010) 104 Proceedings of the Annual Meeting of the American Society of International Law 246-250.

19 Ibid.
} 
The same can be said about the rights to food, water and adequate housing - which are all components of the more general right to an adequate standard of living. ${ }^{20}$ They are also generally regarded as basic necessities of life and socio-economic rights. Availability is an essential element of the right to food, whereas access is similarly essential for water and access to housing. In many African countries, the provision of water, food and housing is done through public procurement. It is in this respect that public procurement corruption becomes a violation of human rights.

A similar argument can be made with respect to the right to health, which, broadly speaking, includes healthcare - but also the underlying determinants of health such as safe drinking water, adequate sanitation, an adequate supply of safe food, nutrition, housing, occupational health, environmental health, and access to health-related information. ${ }^{21}$ According to Terracino 'corruption in the health sector can take many forms, such as bribery of regulators and medical professionals, manipulation of information on drug trials, the diversion of medicines and supplies, and corruption in procurement'. However, in the health sector, it is in hospitals that corruption is probably most noticeable - mainly through opaque procurement of equipment and supplies. It is through such acts that corruption becomes a violation of the right to health. Similar arguments can be made with respect to corruption in the procurement of equipment and supplies in educational institutions and the consequential violation of the right to education.

\subsection{The Adverse Impact of Corruption on Human Rights}

In view of the principles of universality, interdependence and indivisibility of human rights mentioned earlier, it is correct to say that corruption has an adverse impact on the enjoyment of all human rights - civil and political, social, economic and cultural. It is also correct to say, however, that the adverse impact is felt more by disadvantaged and vulnerable groups such as women, children, persons with disabilities, the elderly, indigenous people, and the LG BT community. This is because corruption limits access to public goods and services on which these people ordinarily rely. Moreover, they typically lack resources and knowledge to seek redress and also have limited opportunities to participate in policy formulation and implementation processes. This paper does not offer a detailed discussion on how corruption negatively affects each

20 Article 11(2), International Covenant on Social, Economic and Cultural Rights (ICESCR).

21 ICESCR, General Comment No. 14: The Right to the Highest Attainable Standard of Health (Article 12), U.N. Doc. E/C.12/2000/4, 11 August 2000, para 9. 
individual human rights norm - but briefly discusses the adverse impact of corruption on a few civil and political, social, economic, and cultural rights.

\subsubsection{Impact on Civil and Political Rights}

Corruption can and does have a negative impact on the rights to equality, life, human dignity, political rights, and the right to a fair trial - to mention but a few. In so far as the right to equality is concerned, mention was earlier made of how corruption directly violates this right by producing unequal and discriminatory outcomes and perpetuating inequality. Corruption also perpetuates gender inequalities due to the 'unequal power relations between women and men [that] make women more vulnerable to the impact of corruption. ${ }^{22}$ Moreover, 'corruption creates additional obstacles for women to access and use public goods (including basic services) as well as to participate in their country's political processes'.23

As for the right to life, there are many examples and cases that demonstrate the adverse effect of corruption thereon. In fact, it is usually said that 'corruption kills'. Money lost through corruption could have been spent on feeding starving and malnourished children and stopping numerous preventable deaths that occur in Africa every day due to hunger and starvation. Moreover, corruption also 'affects the right to life in cases where medications and other essentials are not made available in public hospitals because they have been diverted for the private use of senior government officials and their friends ....24 It must be pointed out that the right to life includes the right to live with dignity. The South African Constitutional Court described the rights to life and human dignity as the most important of all human rights and the source of all personal rights. ${ }^{25}$ It is therefore fair to say that poverty induced by corruption denies people their right to dignity.

One area where corruption is quite rampant in Africa, is in the judicial systems and the administration of justice. This usually occurs through bribery, extortion, intimidation and abuse of court procedures - to influence judicial decisions and outcomes. As a result, the right to a fair trial is adversely affected. As with other effects of corruption, it is mainly the vulnerable and

\footnotetext{
22 See: Transparency International, 'Gender equality and corruption: What are the linkages?' Policy Brief No. 01/2014, <https://www.transparency.cz/wp-content/uploads/ TI_Policy_Brief_GenderEqualityCorruption_EN.pdf $>$.

23 Ibid.

24 See: Kolawole Olaniyan Corruption and human rights law in Africa (Hart Publishing, Oxford, 2014) 207.

25 Sv Makwanyane 1995 (3) SA 391 (CC) para 144.
} 
disadvantaged who bear the brunt of such injustice, as they get excluded from access to justice and opportunities to settle their disputes fairly and impartially. The same could be said about the adverse impact of corruption on political rights or the right to make political choices. People living in poverty - which may well be induced by corruption - are denied the chance to make political choices and get involved in the political decisions that affect them.

\subsubsection{Impact on Social, Economic and Cultural Rights}

The rights that fall in this category usually include rights dealing with labour relations; environmental rights; property rights and access to adequate housing, healthcare services; and access to sufficient food and water. They also include access to social security, education, language and culture. The following are examples of ways through which corruption can negatively affect specific rights:

- Property rights - if laws and processes relating to ownership of property are applied and enforced discriminatorily due to bribery or political patronage.

- Labour relations (the right to work) - if recruitment processes for job opportunities are biased in favour of particular applicants instead of being based on merit.

- Right to health - if a person's access to healthcare is restricted or denied because he/she can't pay a bribe; or, as mentioned earlier, if medicines and equipment are diverted from the public healthcare system to private health facilities and personal use; or if resources are drained from health budgets through embezzlement and procurement fraud.

- Right to water - if citizens have to pay bribes to be connected to the municipal or national water grid.

- Right to food - if funds from food programmes designed for the poor are embezzled or diverted.

- Right to education - if funds for building educational institutions or providing educational resources and facilities are embezzled or misappropriated; or if a parent has to pay a bribe to get his/her child into a school.

- Right to housing - if funds for housing programmes for the poor are embezzled; or if officials allocating houses in such programmes have to be bribed.

- Right to social security - if funds meant for social security are embezzled.

The list is not a numerus clausis and is not exhaustive as there are several other examples of ways in which corruption can and does adversely affect socioeconomic rights. It must be pointed out that corruption - particularly public procurement corruption - is more likely to affect socio-economic rights than other rights, because they tend to have social and economic ramifications as 
most reflect specific areas of basic needs or delivery of particular goods and services. These goods and services usually 'generate large public contracts which not only create opportunities for corruption but have a proportionate impact on vulnerable and disadvantaged groups, in particular women.' ${ }^{26}$

In order to appreciate the need for applying a human rights-based approach to combating public procurement corruption, it is important to have a sense of the existing legal frameworks for combating corruption. Almost all countries in Africa have such frameworks. The variation between the frameworks depends, in part, on whether the state has ratified and domesticated the relevant international treaties and other instruments. Before looking briefly at the national legal frameworks of selected African countries, it is therefore important to have a brief overview of the international legal framework on corruption.

\subsection{International}

The main international legal instrument against corruption is the UN Convention against Corruption (UNCAC) ${ }^{27}$ which focuses on prevention, criminalisation, international cooperation, asset-recovery and implementation mechanisms. It recognises public procurement as a critical area and sets specific requirements for the prevention of corruption within this sector, ${ }^{28}$ and enjoins state parties to 'take the necessary steps to establish appropriate systems of procurement, based on transparency, competition and objective criteria in decision-making, that are effective, inter alia, in preventing corruption'. ${ }^{29}$ Another relevant instrument is the United Nations Convention against Transnational Organised Crime. ${ }^{30}$ Although this Convention is aimed mainly at the fight against organised crime, it includes several provisions related to corruption. ${ }^{31}$ Although it does not contain any provision relating directly to public procurement, Article 8 may be applicable to corruption occurring

26 International Council on Human Rights Policy (ICHRP) Corruption and human rights: Making the connection (2009) 45 .

27 UN General Assembly Resolution 58/4 of 2003.

28 Article 9.

29 Article 9(1).

$30 \quad$ UN General Assembly Resolution $55 / 25$ of 15 November 2000.

31 Article 8 provides for the criminalisation of corruption; Article 9 provides for measures against corruption; and Article 10 provides for the liability of legal entities involved in corrupt acts. 
during a public procurement process, as it calls for the criminalisation of acts by public officials, which may involve the giving, offering, acceptance, promise or solicitation of an undue advantage by a public official or to a public official.

In the African context, the African Union Convention on Preventing and Combating Corruption ${ }^{32}$ is most relevant. It emphasises the need for member states to develop mechanisms of preventing, eradicating, and punishing acts of corruption. ${ }^{33}$ Although this Convention does not contain provisions relating directly to public procurement, it does contain provisions which, if adhered to by member states, may have the effect of reducing or preventing public procurement corruption. Article 7 , for example, is dedicated to the fight against corruption and related offences in the public service, whereas Article 8(1) obliges state parties to create, within their domestic legal systems, an offence of illicit enrichment. With respect to tendering procedures, the Convention emphasises the need for transparency, equity and efficiency. ${ }^{34}$ The requirement of member states to adopt legislative or other measures to prevent and combat acts of corruption - in and by the private sector - is critical in the fight against corruption within the public sector. ${ }^{35}$

In so far as the regional framework is concerned, particularly in the context of Southern Africa, the Southern African Development Community Protocol against Corruption ${ }^{36}$ was the first subregional anti-corruption treaty in Africa. Its purpose is to:

a) Promote the development of anti-corruption mechanisms at national level;

b) Promote cooperation in the fight against corruption by State parties; and

c) Harmonise national anti-corruption legislation within Southern African Development Community member states.

As with the AU Convention on Preventing and Combating Corruption, this Protocol calls for codes of conduct for public officials and systems of government hiring and procurement of goods and services, that ensure the transparency, equity and efficiency of such systems - as well as mechanisms for access to information. The Protocol also places a duty on states to provide for mechanisms to detect corruption within the private sector.

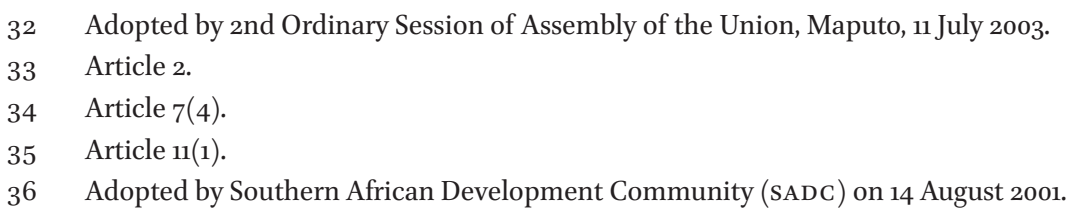


Other international instruments that have some bearing on public procurement corruption in Africa include the oECD Convention on Combating Bribery of Foreign Officials in International Business Transactions ${ }^{37}$ - whose main purpose is to provide a framework for criminalising corruption in international business transactions. They also include the 2011 UnCITRAL Model Law on Public Procurement ${ }^{38}$ which contains international best practices on public procurement procedures and principles in a national setting. It also seeks to harmonise public procurement processes across nations.

\subsection{National: Selected African Countries}

In so far as national legal frameworks are concerned, as mentioned earlier, selected African countries are briefly reviewed here - beginning with South Africa.

\subsubsection{South Africa}

Section 217 of the South African Constitution provides the constitutional basis for public procurement in the country. Section $217(1)$ sets out five constitutional principles on which all procurement practices must be based: fairness, equity, transparency, competitiveness and cost-effectiveness. Section 217(2) recognises that public procurement may be used as a tool to promote social and policy objectives, by, for example, promoting the development of previously disadvantaged groups. ${ }^{39}$ The legislative framework pertaining to public procurement must therefore adhere to and promote these constitutional provisions. ${ }^{40}$ Accordingly, national legislation and subordinate legislation in the form of regulations have been enacted to respond to the constitutional principles and the integrated supply chain management process. One such statute is the Public Finance Management Act (PFMA), ${ }^{41}$ which was adopted to modernise financial management and enhance accountability. It sets out procedures for efficient and effective management of all revenue, expenditure, assets and liabilities - and establishes the duties and responsibilities

37 Adopted by Negotiating Conference on 21 November 1997.

38 General Assembly Resolution 66/95 of 9 December 2011.

39 Supra note 15, p. 34.

40 The Constitutional Court in AllPay Consolidated Investment Holdings (Pty) Ltd v Chief Executive Officer of the South African Social Security Agency 2014 (1) SA 604 (CC) para 32, stated that the starting point for an evaluation of the proper approach to an assessment of the constitutional validity of outcomes under the state procurement process, is thus $\mathrm{s}$ 217 of the Constitution.

$41 \quad 1$ of 1999 . 
of government officials in charge of finances. Section 38 PFMA sets out the general responsibilities of accounting officers, ${ }^{42}$ and section 76 (4)(c) requires the National Treasury to make regulations or issue instructions applicable to departments concerning the determination of a framework for an appropriate procurement and provisioning system which is fair, equitable, transparent, competitive and cost-effective.

Another relevant statute is the Municipal Finance Management Act (MFMA), ${ }^{43}$ which is mainly applicable to municipalities in the local sphere of government. As with the PFMA, the MFMA is not dedicated solely to procurement, but provides the legal framework for the implementation of an integrated supply chain management process in local government. Also relevant is the Preferential Procurement Policy Framework Act (PPPFA) ${ }^{44}$ whose purpose is to give effect to section 217(3) of the Constitution, by providing a framework for the implementation of the procurement policy contemplated in section 217(2) of the Constitution. Then there is the Local Government: Municipal Systems Act, ${ }^{45}$ which provides that municipalities may procure the services of private persons to provide or perform a municipal service. ${ }^{46}$ The Act makes it incumbent on municipalities to employ a competitive bidding process which complies with the relevant provisions of the MFMA when procuring such services. ${ }^{47}$ Section $83(1)(d)$ requires that the selection during competitive bidding must make the municipality accountable to the local community regarding progress with selection, and reasons for any decisions made. The provisions of the Municipal Systems Act are directly applicable to public procurement when the good or service procured is required to fulfil a municipal service. Another relevant statute is the Promotion of Administrative Justice Act ${ }^{48}$ - to the extent that the award of a contract in terms of the public procurement process constitutes administrative action.

\footnotetext{
$42 \mathrm{~S}_{3} 6$ of the PFMA defines an accounting officer as the head of a department or the CEO of a constitutional institution.

4356 of 2003 .

445 of 2000.

4532 of 2000.

$46 \quad \mathrm{~S} 8 \mathrm{o}(1)(\mathrm{b})$. A municipal service is defined in $\mathrm{s} 1$ as a service that a municipality in terms of its powers and functions provides or may provide to or for the benefit of the local community, irrespective of whether such service is provided through an internal or external mechanism and irrespective also of whether fees, charges or tariffs are levied in respect of such a service or not.

$47 \quad$ S $83(1)(a)$.

483 of 2000 .
} 
The Prevention and Combating of Corrupt Activities Act (PCCA) ${ }^{49}$ is the chief anti-corruption statute in South Africa, but it is not solely applicable to public procurement corruption. It provides for a general offence of corruption ${ }^{50}$ and creates offences in respect of corrupt activities relating to specific persons, ${ }^{51}$ offences in respect of parties in an employment relationship, ${ }^{52}$ offences in respect of corrupt activities relating to specific matters, ${ }^{53}$ and miscellaneous offences relating to possible conflict of interest and other unacceptable conduct. ${ }^{54}$ It also provides for offences accessory to or after an offence, attempt, conspiracy and inducing another person to commit an offence. ${ }^{55}$ Section 13 applies to corruption in respect of corrupt activities relating to the procuring and withdrawal of tenders. Sections 24 and 25 create certain statutory presumptions and defences - whereas sections 29-33 of the PCCA apply to the register for tender defaulters. The Act also provides for the establishment of a national register of tender defaulters within the Office of the National Treasury. ${ }^{56}$

In so far as subsidiary legislation is concerned, mention must also be made of the PFMA Regulations ${ }^{57}$ which are intended to provide a practical framework within which supply chain management practices are to take place, the MFMA: Municipal Supply Chain Management Regulations ${ }^{58}$ which provide essentially the same procedure for competitive bidding procurement, and the PFMA Regulations and Preferential Procurement Policy Framework Act Regulations ${ }^{59}$ issued in terms of section $5(1)$ of the PPPFA which provide an

$49 \quad 12$ of 2004.

$50 \quad \mathrm{~S}_{3}$.

51 Ss 4-9 create offences in respect of corrupt activities relating to public officers, foreign public officials, agents, members of legislative authority, judicial officers, and members of the prosecuting authority.

52 S 10 .

53 Ss 11-16 create offences relating to: witnesses and evidential material during certain proceedings, contracts, procuring and withdrawal of tenders, auctions, sporting events, and gambling or games of chance.

54 Ss $17-19$.

55 Ss $20-21$.

56 S 29 .

57 Republic of South Africa National Treasury: Treasury Regulations for Departments, Trading Entities, Constitutional Institutions and Public Entities. Issued in terms of the PFMA. (2005) Government Gazette No 27388.

$5^{8}$ Republic of South Africa National Treasury Local Government: Municipal Finance Management Act 56 of 2003: Municipal Supply Chain Management Regulations (2005) Government Gazette No 27636 .

59 Preferential Procurement Policy Framework Act, 2000: Preferential Procurement Regulations, 2011, Gazette No 34350. The 2011 Regulations have replaced the Preferential Procurement Regulations, 2001, as published in Government Gazette Number R 725 . 
operational framework for the preference point system envisaged in the PPPFA. In addition to the above statutes and regulations, many Treasury prescripts apply to public procurement in South Africa. These prescripts are issued either in terms of section 76(c) of the PFMA or section 168 (1)(a) of the MFMA. A detailed discussion of these is neither necessary nor possible.

\subsubsection{Nigeria}

One persistent but dubious accolade conferred on Nigeria is that it is one of the most corrupt countries in the world. ${ }^{60}$ Although the Nigerian Constitution does not provide for constitutional procurement principles as does the South African Constitution, it does charge the state to abolish all corrupt practices and the abuse of power. ${ }^{61}$ It also sets out provisions which promote the planned use of public funds - in accordance with pre-approved expenditure. ${ }^{62}$ In addition, it sets out certain fundamental objectives, of which the abolishing of corruption is one. These objectives are contained in Chapter II, as Directive Principles of State Policy. It has been argued that these directives are generally seen as guidelines for government, and cannot be enforced in the courts to the same extent as other fundamental rights. ${ }^{63}$

In terms of legislation pertaining to public procurement, the most relevant statute is the Public Procurement Act (PPA) of 2007, which has elements of the UNCITRAL Model Law and therefore incorporates international best practices in many respects. Regulations have also been issued in terms of the P PA known as the Public Procurement (Goods and Works) Regulations. ${ }^{64}$ The PPA - read together with the Regulations - provides a framework within which competitive bidding and other methods of procurement are implemented. It also provides for publication of bids. Other important aspects of the Act include the establishment of a Bureau of Public Procurement, ${ }^{65}$ and the criminalisation of certain procurement-related offences, ${ }^{66}$ to mention but a few.

In so far as anti-corruption legislation, in general, is concerned, the main statute is the Corrupt Practices and Other Related Offences Act, ${ }^{67}$ which

\footnotetext{
6 M. Salisu Corruption in Nigeria (2006) Lancaster University Management School Working paper 2000/006.

61 S 15(5), Nigerian Constitution.

62 Ss 80 and 162.

63 S. Khoza 'Chapter one' in Introducing socio-economic rights in South Africa: A resource book (Community Law Centre, University of the Western Cape, Cape Town, 2007).

$64 \quad 2007$.

$65 \mathrm{~S}_{3}(1)$.

66 Part XII of the PPA.

675 of 2000.
} 
applies to all public officials and criminalises bribery and attempted corruption, abuse of office, fraud, extortion and money laundering. It criminalises any giving, receiving, asking or accepting of any property, benefit or gratification, from or to any person with a corrupt intention. One of the special features of the Act is that it prohibits public officials from holding any private interest in any contract, agreement or investment which is connected with the office or department in which they are employed. ${ }^{68}$ The Act also seems to recognise that corruption may occur outside the realm of an offer and acceptance of some undue gratification or reward. Section 19 provides that any public officer who uses his position or office for his own unlawful advantage, shall be guilty of an offence. Furthermore, evidence of tradition or custom in the offering and/or acceptance of gratification is inadmissible. ${ }^{69}$

Other anti-corruption laws include the anti-corruption provisions of the PPA, the Advance Fee Fraud and other Fraud Related Offences Act ${ }^{70}$ which was enacted to combat the large body of fraudulent activities that negatively impacted Nigeria's business reputation, the Fiscal Responsibility Act ${ }^{71}$ which was aimed at improving budgeting and reducing opportunities for corruption, and the Money Laundering (Prohibition) Act ${ }^{72}$ which criminalises individuals and corporate bodies making or accepting cash payments in excess of certain amounts without going through a financial institution. The Economic and Financial Crimes Commission Act ${ }^{73}$ establishes a second agency known as the Economic and Financial Crimes Commission (EFCC), which is dedicated to the investigation of financial crimes such as fraud and money laundering, and enforces legislation like the Advance Fee Fraud and other Fraud Related Offences Act and the Money Laundering Act.

\subsubsection{Botswana}

Botswana is generally perceived as the least corrupt country in Africa. However, Botswana is not immune from corruption - including public procurement corruption.

In so far as legislation governing public procurement is concerned, it is important to note that unlike South Africa, the Botswana Constitution does not make provision for constitutional procurement principles. The Public

\begin{tabular}{ll}
\hline 68 & S 12. \\
69 & S 6o. \\
70 & Cap A6 of 2006. \\
71 & 31 of 2007. \\
72 & 11 of 2011. \\
73 & 2004.
\end{tabular}


Procurement and Asset Disposal Act (PPADA) ${ }^{74}$ regulates public procurement at central government level. It sets out high-level directives applicable to procurement by central government. Defined processes and procedures relating to these directives are contained in Regulations published in terms of section 130 of PPADA. The Local Authorities Procurement and Asset Disposal Act regulates public procurement at local government level. The Local Authorities Procurement and Asset Disposal Regulations ${ }^{75}$ provide details on the processes to be followed in a procurement process at local government level.

The PPADA establishes the Public Procurement and Public Asset Disposal Board. ${ }^{76}$ Unlike South Africa where procurement decisions are taken by individual departments and municipalities without a dedicated board or other body tasked with the oversight of procurement processes, the Procurement Board in Botswana is responsible for the supervision of all procurement decisions. The Procurement Board has also issued a detailed Operations Manual on Standard Operating Policies and Procedures for Public Procurement. ${ }^{77}$ In terms of section 26 thereof, the Procurement Board must ensure that all procuring and disposal entities undertake procurement processes, taking into account, inter alia, the principles of competition, fairness, equity, accountability and transparency. The Procurement Board also has the power to adjudicate a bid where bid recommendations are submitted to it by competent bodies. ${ }^{78}$

The main anti-corruption law in Botswana is the Corruption and Economic Crime Act, ${ }^{79}$ which creates offences and places them in different categories. Most of the categories of offences relate to corruption by or of a public officer. ${ }^{80}$ In essence, the elements of an offence of corruption include the giving or acceptance of some valuable consideration ${ }^{81}$ to or by a public officer in exchange for the public officer's improper use of his office or official influence. Section 34 allows the Director of the Directorate on Corruption and Economic Crime ${ }^{82}$ to investigate any person where there are reasonable grounds to suspect that such a person maintains a standard of living above that which is commensurate

74 [Cap 42:08] of 2001.

75 [Cap 42:11] of 2009 .

76 S 10.

$77 \quad 2013$.

78 S 37 .

79 Cap 08:05.

8o In this respect, see ss 24, 25, 26, 27, 29, 31 and 33 of the Corruption and Economic Crime Act 13 of 1994 .

81 The term 'valuable consideration' is given a wide definition in terms of s 2 .

82 In South Africa, this authority is given to the National Director of Public Prosecutions, after such Director has obtained an investigation order from a court. 
with his present or past sources of income. The Act places a duty on the suspect to offer a satisfactory explanation as to how she or he was able to maintain such a standard of living - failing which the suspect is deemed to be guilty of corruption. Section 42 creates a presumption of corruption. This presumption applies to all offences created in the Act. In terms of this presumption, where the prosecution has proved the offer or acceptance of a valuable consideration, a presumption is created that such consideration was offered or accepted as an inducement or reward, as alleged in the particulars of the offence concerned.

As does the law in Nigeria, the Corruption Act in Botswana establishes an independent agency dedicated to its enforcement. The Corruption Act grants the Directorate on Corruption and Economic Crime investigative powers including the powers of arrest without warrant ${ }^{83}$ and of search and seizure. ${ }^{84}$ This anti-corruption agency also performs other functions like educating the public against the evils of corruption, ${ }^{85}$ enlisting and fostering public support in combatting corruption, ${ }^{86}$ and advising and assisting people on ways in which corrupt practices may be eliminated. ${ }^{87}$

\subsubsection{Kenya}

Article 227 of the Constitution of Kenya requires any state organ or any other public entity contracting for goods or services, to do so in accordance with a system that is fair, equitable, transparent, competitive and cost-effective. ${ }^{88}$ The Constitution also provides for the enactment of legislation to prescribe a framework within which policies relating to procurement and asset disposal shall be implemented. ${ }^{89}$ The legislation should also provide for categories of preference in the allocation of contracts; the protection or advancement of persons, categories of persons or groups previously disadvantaged by unfair competition or discrimination; sanctions against contractors that have not performed according to professionally regulated procedures, contractual agreements or legislation; and sanctions against persons who have defaulted on their tax obligations, or who have been guilty of corrupt practices or serious violations of fair employment laws and practices. ${ }^{90}$

\begin{tabular}{ll}
\hline 83 & S 10(1). \\
84 & S 11. \\
85 & S 6 (i). \\
86 & S 6(j). \\
87 & S 6(g). \\
88 & Article 227(1). \\
89 & Article 227(2). \\
90 & Ibid.
\end{tabular}


To give effect to Article 227 of the Constitution, the Public Procurement and Asset Disposal Act ${ }^{91}$ was enacted in 2015. Among other things, the Act provides guiding principles for public procurement and asset disposal for state organs and public entities, ${ }^{92}$ and outlines general principles of procurement and disposal. ${ }^{93}$ It also establishes the Public Procurement and Regulatory Authority (PPRA) to monitor, assess and review the public procurement and asset disposal system. ${ }^{94}$ Although the Act appears to be innovative and comprehensive, it has been criticised by some for containing 'various controversial provisions including the requirement by a bidder, who wishes to challenge the decision of a procuring body, to deposit $10 \%$ of the bid price before the Review Board will accept a request for review'.95 The Act also introduces new deadlines which some think are unlikely to work in practice. ${ }^{96}$

In so far as ant-corruption law is concerned, the main statute in Kenya is the Anti-Corruption and Economic Crimes Act ${ }^{97}$ which provides for the prevention, investigation and punishment of corruption, economic crime and related offences. In addition to establishing special magistrates to adjudicate corruption cases, ${ }^{98}$ the Act established two important anti-corruption institutions: an Anti-Corruption Commission ${ }^{99}$ and an Anti-Corruption Advisory Board. ${ }^{100}$ Another anti-corruption statute is the Public Officers Ethics Act, ${ }^{101}$ whose main purpose is to advance the ethics of public officers by providing a code of conduct and ethics for public officers and requiring financial declarations from certain public officers. The code of conduct and ethics imposes on public officers a duty of professionalism and prohibits activities such as improper enrichment, conflicts of interest, acting for foreigners, political partisanship, nepotism, and sexual harassment.

\footnotetext{
9133 of 2015 .

$92 \quad \mathrm{~S}_{3}$.

$93 \mathrm{~S} 53$.

94 S 8.

95 See: Daly \& Inamdar 'The Public Procurement and Asset Disposal Act, 2015' < http://www. dalyinamdar.com/the-public-procurement-and-asset-disposal-act-2015/>.

$96 \quad$ Ibid.

973 of 2003 .

98 Part 2 of the Act.

99 S 6. This was amended in 2011 by the Ethics and Anti-Corruption Commission Act in order to change the Anti-Corruption Commission to the Ethics and Anti-Corruption Commission.

$100 \mathrm{~S} 16$, as amended by the Ethics and Anti-Corruption Commission Act, 2011.

101 Cap 183 of 2003, as revised in 2009.
} 


\subsubsection{Uganda}

The main statute regulating public procurement in Uganda is the Public Procurement and Disposal of Public Assets Act of 2003. The main purpose of the Act is to ensure the application of fair, competitive, transparent, nondiscriminatory and value-for-money procurement and disposal standards and practices. It establishes the Public Procurement and Disposal of Public Assets Authority (PDDA) to harmonise the procurement and disposal policies, systems and practices of the central government, local governments and statutory bodies - to set standards for the public procurement and disposal system in Uganda and to monitor compliance with existing laws and regulations, among other things. ${ }^{102}$ The Act is 'complemented by Regulations, Guidelines, Forms and Standard Bidding Documentation which serve to assist the procuring and disposing entities and providers of services, supplies and works in carrying out procuring and disposing processes'. ${ }^{103}$ The Act was amended in 2011 to provide for further functions and powers of the PDDA, to establish the Public Procurement and Disposal of Public Assets Tribunal, and to create new offences, among other things.

In terms of anti-corruption legislation, the Anti-corruption Act of 2009 is the main statute. It defines corruption as 'soliciting and acceptance of anything by a public official, diversion of public funds, as well as fraudulent acquisition and concealment of property'. The Act regulates corruption in both the public and private sector. The Act has been criticised as being 'a piece of criminal legislation that classifies certain acts and omissions as offences, and then sets out the punishment for each such offence - usually a fine, jail term or both. ${ }^{104}$ Consequently, the Anti-Corruption (Amendment) Act was passed in 2015 'to provide for the mandatory confiscation of property of a person convicted of an offence under the Act and for the procedure for issuing a confiscation order', among other things. ${ }^{105}$

The other important statute is the Leadership Code Act 2002, which provides for a minimum standard of behaviour and conduct for leaders - and to require leaders to declare their incomes, assets and liabilities, and those of their spouses and children aged under 18 years. Also relevant is the Whistleblowers

\footnotetext{
$102 \quad S 6$.

103 PDDA 'Report on the compliance and performance indicators for the Uganda procurement system' <http://www.oecd.org/development/effectiveness/41050415.pdf>.

104 See: I. Akurut 'An analysis of the Anti-Corruption (Amendment) Bill No. 7 of 2013', <http:// parliamentwatch.ug/an-analysis-of-the-anti-corruption-amendment-bill-no-7-of-2013/>.

105 Preamble to the Act.
} 
Protection Act, ${ }^{106}$ section 2(1) of which provides that a person may make a disclosure of information where that person reasonably believes that the information tends to show that a corrupt, criminal or other unlawful act has been committed, is being committed, or is likely to be committed.

\section{A Human Rights-Based Approach}

Clearly, the national legal frameworks for combating corruption in many, if not all African countries, do not include a human rights perspective - even though many of them have constitutions that contain bills of rights. It is also despite the knowledge and realisation that corruption undermines the principles and values of basic human rights. It is in that context that a human rights-based approach is proposed.

A human based rights-based approach has been described as:

... about empowering people to know and claim their rights and increasing the ability and accountability of individuals and institutions who are responsible for respecting, protecting and fulfilling rights. This means giving people greater opportunities to participate in shaping the decisions that impact on their human rights. It also means increasing the ability of those with responsibility for fulfilling rights to recognise and know how to respect those rights, and make sure they can be held to account. ${ }^{107}$

Taking this into account, adopting a human rights approach to combating public procurement corruption requires the integration of human rights principles and institutions into anti-corruption strategies. It means that fighting public procurement corruption - indeed all corruption - should be done from a human rights perspective. According to the former Un High Commissioner for Human Rights, Navi Pillay, 'a human rights-based approach to anti-corruption responds to the people's resounding call for a social, political and economic order that delivers on the promises of freedom from fear and want'.108 This is mainly because:

\footnotetext{
$106 \quad 6$ of 2010.

107 Scottish Human Rights Commission 'What is a human rights based approach?', <http:// www.scottishhumanrights.com/careaboutrights/whatisahumanrightsbasedapproach>.

108 Navi Pillay 'The human rights case against corruption', panel discussion, 27 March 2013, $<$ http://www.ohchr.org/EN/NewsEvents/Pages/HRCaseAgainstCorruption.aspx >.
} 
... corruption violates the core human rights principles of transparency, accountability, non-discrimination and meaningful participation in every aspect of life of the community. Conversely, these principles, when upheld and implemented, are the most effective means to fight corruption. ${ }^{109}$

In adopting a human rights-based approach to combating public procurement corruption, a number of things must be done. First, all African countries have to ratify and domesticate all relevant international and regional human rights and anti-corruption instruments. This will enable those countries to draw on the international legal framework and best practice to fight corruption. Second, a comprehensive response to corruption requires more than appropriate laws and legal frameworks. It also requires good governance and effective institutions. Accordingly, it requires the establishment of effective and efficient constitutional and human rights institutions. For example, the role of the Public Protector in fighting corruption in South Africa is very well known. The Office of the Public Protector is established in Chapter 9 of the South African Constitution, in support of constitutional democracy. All ombudsman and human rights institutions in African countries should be playing such a role. More specifically, and despite the existence of anti-corruption commissions in some African countries, ombudsman and human rights institutions should have the specific mandate of investigating and punishing public procurement corruption.

It is also important to point out that the adoption of legal frameworks, the creation of anti-corruption commissions, and the establishment of constitutional and human rights institutions, may be ineffective unless there is strong civil society engagement and participation. This is because civil society plays a key role in fighting corruption. This can be done through public awareness campaigns, civil activism, education, training and networking activities that characterise the activities of civil society formations. It can also be done through civil society participation in decision-making processes that can contribute to enhancing transparency and fairness. Moreover, the fight against public procurement corruption requires strong political will on the part of government and the existence of a strong, influential public opinion. Civil society is best placed to influence the political will and provide influential public opinion. This must be seen in the context of the point made earlier - that a human rights-based approach empowers ordinary people (who form civil society) to demand transparency, accountability and responsibility from elected

109 Ibid. 
representatives and public officials, and particularly those involved in public procurement.

An important component of a human rights-based approach is individual integrity on the part of leaders, public officials and individual citizens. 'Integrity' has been defined as 'the expected action and responsibility of individuals and organisations in prevention and elimination of the risk that any authority, office, power or another competence for decision-making is used contrary to the law, legally permissible objectives or codes of ethics.'110 Clearly, integrity is an important requisite for government officials - especially those who work in public procurement. It must be emphasised, however, that the need for individual integrity is not restricted to leaders and public officials; it should extend to all citizens and ordinary people. This is important in the context of a human rights-based approach to combating corruption, because, as mentioned earlier, human rights belong to all human beings by virtue of their being human. Citizens with individual integrity are better placed to demand the protection of their rights and to play an important role in fighting corruption.

Mention was made earlier of one school of thought that sees corruption as being a violation of human rights and another that perceives corruption as merely having an adverse impact on the enjoyment of human rights. Taking these two schools of thought together - it would appear that the best way to adopt a human rights-based approach to combating corruption is by institutionalising the right to freedom from corruption. In other words, criminalising corruption alone is not enough. A human right to freedom from corruption should be developed and incorporated into African human rights instruments and national constitutions. ${ }^{111}$ This could begin at the continental (African Union) level to regional level - and then further down to the national level. The right would be able to spell out the forms of corruption against which individuals are protected - including public procurement corruption. All the elements associated with human rights, such as right-holder and duty-bearer, would apply, and the right would have vertical and horizontal application as it would be enforceable against individuals and the state. This would not only enhance the empowerment of individual citizens, but also strengthen the role of civil society in fighting corruption. Moreover, it would bring the judiciary

110 Article 4(3), Integrity and Prevention of Corruption Act (2010) of the Republic of Slovania.

111 The creation of a right to freedom from corruption was initially proposed by Kumar in relation to Hong Kong. See: C. Raj Kumar: 'Human rights approaches of corruption control mechanisms - Enhancing the Hong Kong experience of corruption prevention strategies' (2004) 5 San Diego International Law Journal 323-351. 
with all its judicial apparatus and enforcement mechanisms into the fight against corruption.

\section{$5 \quad$ Conclusion}

There are several reasons why this paper has focused on public procurement corruption. According to Corruption Watch, for example 'while the concern about corruption is a general one, it applies with particular force in the context of public procurement'.112 This sentiment is shared by many commentators including Bolton, who has opined that '... the size and volume of government procurement does give rise to considerable potential for corruption. Both contractors and public officials may resort to corrupt practices.'13 Furthermore, according to Williams-Elegbe:

... public procurement is susceptible to corruption due partly to the large sums involved, the (usually) non-commercial nature of procuring entities, the nature of the relationship between the decision-maker and the public body, the measures of unsupervised discretion, bureaucratic rules and budgets that may not be tied to specific goals as well as non-performance-related pay and low pay. ${ }^{114}$

In proposing a human rights-based approach to combating public procurement corruption in Africa, this paper began by exploring the link between human rights and corruption generally. Two strands were highlighted. First, that corruption has an adverse impact on human rights, and, second, that it is a violation of human rights. Existing legal frameworks were discussed in order to reveal that there are numerous potential legislative mechanisms to prevent and combat corruption and regulate public procurement in African countries. However, such legal frameworks and legislative mechanisms do not include a human rights perspective. It was then proposed that a human rights-based approach should be adopted. This requires the ratification and domestication of all relevant international and regional human rights and anti-corruption

\footnotetext{
112 Corruption Watch Practice Note and Written Submissions in AllPay Consolidated Investment Holdings (Pty) Ltd v CEO of the South African Social Security Agency (ibid) para 14 .

113 Supra note 15, p. 4.

114 Sope Williams-Elegbe Fighting corruption in public procurement: A comparative analysis of disqualification or debarment measures (Hart Publishing, Oxford, 2012) 24-25.
} 
instruments; the creation of anti-corruption commissions and the establishment of constitutional and human rights institutions; strong civil society engagement and participation; strong political will on the part of government; and individual integrity on the part of leaders, public officials and individual citizens.

Most importantly, however, a human rights-based approach to combating public procurement corruption requires the creation and institutionalisation of the right to freedom from corruption - with public procurement corruption being one of the forms against which individuals should be protected. This would go a long way in terms of espousing a human rights-based approach to combating public procurement corruption in Africa. This has been similarly espoused elsewhere by Opeoluwa Adetoro Ogundokun, ${ }^{115}$ whose research on combating corruption in Africa concluded with the suggestion that combating corruption should move beyond a law enforcement and public policy issue and attain the status of a human right - in order to supplement and enhance the institutional approach to tackling corruption which was discussed earlier in this paper.

115 Opeoluwa Adetoro Ogundokun, 'A human rights approach to combating corruption in Africa: Appraising the AU Convention using Nigeria and South Africa, (LLM thesis, University of Pretoria, 2005). 